\title{
基于固体等离子体的阿秒高次谐波产生理论 与实验进展
}

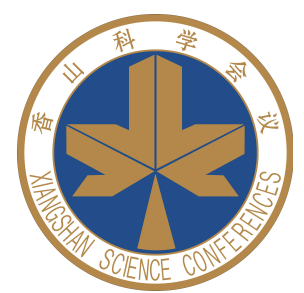

吴家其 ${ }^{1,2}$, 曾志男 ${ }^{2 *}$, 李儒新 ${ }^{1,2}$

1. 上海科技大学物质科学与技术学院, 上海 201210 ;

2. 中国科学院上海光学精密机械研究所, 强场激光物理国家重点实验室, 上海 201800

*联系人, E-mail: zhinan_zeng@mail.siom.ac.cn

2020-05-14 收稿, 2020-06-22 修回, 2020-06-24 接受, 2020-06-25 网络版发表

国家自然科学基金(91950203)和中国科学院战略性先导科技专项(B类)(XDB16)资助

摘要自从2001年首次产生并测量了阿秒(attosecond, $1 \mathrm{as}=10^{-18} \mathrm{~s}$ )脉冲之后, 高次谐波和阿秒脉冲在原子分子物 理、材料科学等领域得到了广泛的应用。但是, 由于气体高次谐波方法产生的阿秒脉冲效率较低, 阿秒脉冲能量受 限, 限制了阿秒时间动力学研究的探测方式(目前主要是IR(infrared)+XUV(extreme ultraviolet)原浦/探测)及其在许 多领域的应用。如何获得高亮度、大能量的阿秒脉冲一直是该领域的追求。高强度的相对论飞秒激光脉冲与固体 密度等离子体相互作用, 在高亮度、大能量高次谐波和阿秒脉冲产生上具有独特的优势, 甚至可能获得远高于原 浦激光场强的谐波电场强度. 本文对基于固体等离子体的阿秒高次谐波产生的物理机制和目前的实验研究进展作 简要介绍。

关键词高次谐波, 阿秒脉冲, 相对论激光, 等离子体

自从激光器被发明之后，谐波产生和波长转换就 一直是非线性光学中的重要研究课题. 1987 年, McPherson等人 ${ }^{[1]}$ 利用亚皮秒氟化氪 $(\mathrm{KrF})$ 激光 $(248 \mathrm{~nm})$ 与惰性气体相互作用首次获得气体高次谐波辐射, 此 后气体高次谐波产生在理论、实验和应用方面都取得 了巨大的进展. 利用气体高次谐波的宽带光谱特性, 2001年, 奥地利维也纳技术大学(Vienna University of Technology)的Krausz研究组 ${ }^{[2]}$ 在实验上成功地利用气 体高次谐波产生并测量了脉冲宽度为 650 as的单阿秒 脉冲. 同年, Paul ${ }^{[3]}$ 利用气体高次谐波产生并测量了脉 宽为 250 as的阿秒脉冲链. 目前, 气体高次谐波已经可 以产生脉冲宽度短至 43 as的超短脉冲 ${ }^{[4]}$, 但是气体高次 谐波产生效率相对较低, 尤其是高光子能量段, 限制了 它在许多领域的应用 ${ }^{[5]}$.
随着激光技术的发展, 飞秒激光系统的输出峰值 功率在近些年得到了飞速的提升, 目前已可以输出峰 值功率高达 $10 \mathrm{PW}\left(1 \mathrm{PW}=10^{15} \mathrm{~W}\right)$ 的激光脉冲, 未来还 可能提高到 $200 \mathrm{PW}$ 的水平, 这为高亮度、大能量高次 谐波和阿秒脉冲的发展带来了新的机会. PW级高功率 激光脉冲的可聚焦光强可远远超过相对论光强 ${ }^{[6]}$, 其与 固体密度等离子体相互作用可以高效率地产生数百 $\mathrm{eV}$ 乃至数 $\mathrm{keV}$ 水平的高次谐波(图1) ${ }^{[7]}$, 为高次谐波和阿秒 脉冲的发展和应用带来了新的机会.

\section{1 物理机制的探索}

飞秒激光脉冲与固体靶相互作用产生高次谐 波 $^{[8,9]}$, 其中的等离子体介质使得泵浦激光光强可以不 受限制地提高, 而谐波辐射则来自电子的集体运动, 其 


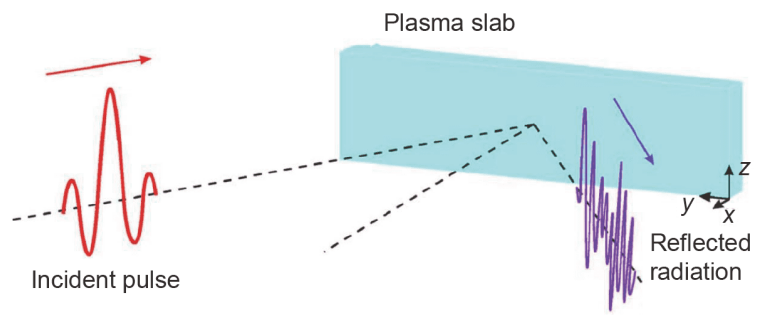

图 1 (网络版彩色)激光脉冲与固体等离子体相互作用产生高次谐 波辐射的示意图 ${ }^{[7]}$. 左边人射激光(incident pulse)聚焦到固体表面与 等离子体(plasma slab)相互作用, 在反射方向上产生辐射(右边, reflected radiation)

Figure 1 (Color online) Schematic diagram of the interaction between a laser pulse and solid plasma to generate high-order harmonic radiation ${ }^{[7]}$. The incident pulse on the left is focused onto the solid surface and interacts with the plasma (plasma slab) to generate radiation in the direction of reflection (right, reflected radiation)

辐射特性具有完全不同的性质, 不同的激光参数和不 同的等离子体条件下存在完全不同的物理机制. 早期 飞秒激光脉冲与等离子体相互作用产生高次谐波主要 基于振荡镜模型(oscillating mirror model, OMM), 即激 光在临界电子密度面被反射，在激光作用下，该界面 $X(t)$ 会发生振荡(图2(a)), 振荡的界面周期性地调制反 射光的相位, 通过多普勒效应产生谐波辐射, 即振荡镜 模型. 对于振荡镜模型，Lichters等人 ${ }^{[10]}$ 和Bulanov等 人 $^{[11]}$ 最早给出了一个解析理论模型. 在相对论激光强 度下，Gordienko等人 ${ }^{[12]}$ 在考虑了等离子体表面上的电 流运动后, 得到谐波谱强度的标度定律为 $I_{n} \propto n^{-2.5 ~-3}$, 谐波的最高级次则由相对论多普勒效应得到, 为 $4 \gamma_{\text {max }}{ }^{2}$ (这里, $n$ 是产生的谐波级次; $I_{n}$ 是相应的谐波谱强度; $\gamma_{\max }$ 是电子的最大洛伦兹因子，取决于泵浦激光的光 强). 进一步, 在超相对论光强下, Gordienko和Pukhov ${ }^{[13]}$ 利用等离子体自相似理论, 认为在超相对论情况下, 表 面运动的 $\gamma$ 因子(表面电子运动的相对论洛伦兹因子, 表 征电子能量变化)是一个很锐的尖峰, 得到谐波辐射的 强度标度定律为 $I_{n} \propto n^{-8 / 3}$, 最高级次不是正比于 $\gamma_{\max }{ }^{2}$, 而 是正比于 $\gamma_{\text {max }}{ }^{3}$ (图3 $)^{[7]}$. 该结果意味着, 随着激光光强提 高到相对论光强以上, 相对论振荡镜(relativistic oscillating mirror, ROM)产生的谐波级次(光子能量)将以三 次方迅速增长, 可以有效获得极高频的谐波辐射, 脉冲 宽度有望可以突破阿秒而达到入秒(zeptosecond, $10^{-21} \mathrm{~s}$ ) 时间尺度, 这对超短脉冲产生研究具有重要的 意义. 由于需要把等离子体表面看作镜面, 这种机制对 驱动激光的对比度有很高的要求, 其最优的等离子体 标度长度在 $0.1 \lambda$ ( $\lambda$ 为驱动激光波长) 的量级水平.

作为次级光源，高次谐波/阿秒脉冲的产生效率始 终是一个重要问题. ROM反射的宽带光谱产生效率随 着谐波级次 $N$ 的提高基本呈现幂指数规律 $N^{-p}$ 下降. 但 是, 尽管开展了大量的理论研究, 对于高阶谐波效率目 前尚不完全清楚 ${ }^{[15]}$. 幂指数 $p$ 决定了谐波产生效率，与 等离子体状态密切相关. 研究表明, ROM机制的幂指数 $p$ 在理想情况下是 $8 / 3^{[7,14]}$. 但是, 这种谐波产自界面(镜 面)瞬时反射的图像对于等离子体显然过于简单，它完 全忽略了激光脉冲能量在等离子体中的沉积效应. 事 实上，在激光强度较高或者等离子体密度不是太高的 情况下，激光能量会有很高比例甚至高达 $60 \%$ 的能量 沉积到等离子体中，电子位移就像弹簧被压缩一样吸
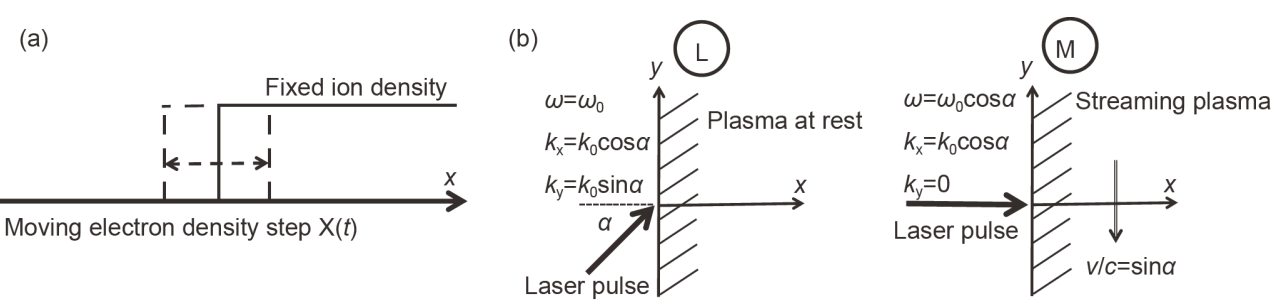

图 2 振荡镜模型 ${ }^{[10]}$. (a) 等离子体分布示意图. 等离子体表面被看作一个陡峭的台阶型分布(镜面)将人射激光反射, 其位置 $X(t)$ 随时间变化. 其 中, 虚线表示电子密度分布, 实线表示离子分布. 这里, 离子密度分布(实线)固定, 电子密度分布(虚线)台阶在激光作用下可以左右移动. (b) 物理 模型处理. 在实验室坐标系 $(\mathrm{L})$ 中, 激光脉冲以任意人射角 $\alpha$ 人射到固体表面 $(x=0)$. 在解析推导和部分数值模拟中, 需要将这个任意角度人射的情 况变换成激光垂直人射到等离子体表面的坐标系(M)中. 这里给出激光垂直人射靶面的坐标系与实验室坐标系之间各个物理量之间的变换关系 Figure 2 The $\mathrm{OMM}^{[10]}$. (a) Schematic diagram of plasma distribution. The plasma surface is regarded as a steep stepped distribution (like mirror) to reflect the incident laser. Its position $X(t)$ changes with time. The dotted curves represent the electron density distribution. The electron density distribution step can move left and right under the interaction with the laser. The solid curves indicate the ion distribution, which is fixed. (b) Physical model. In the laboratory coordinate system (L), the laser pulse is incident on the solid surface $(x=0)$ at any angle $\alpha$. In the analytical derivation and some numerical simulations, it is necessary to transform this incident situation at any angle to be perpendicularly incident on the plasma surface for the laser in a coordinate system $(\mathrm{M})$, where relationship between the physical quantities between the coordinate system and the laboratory coordinate system is given 

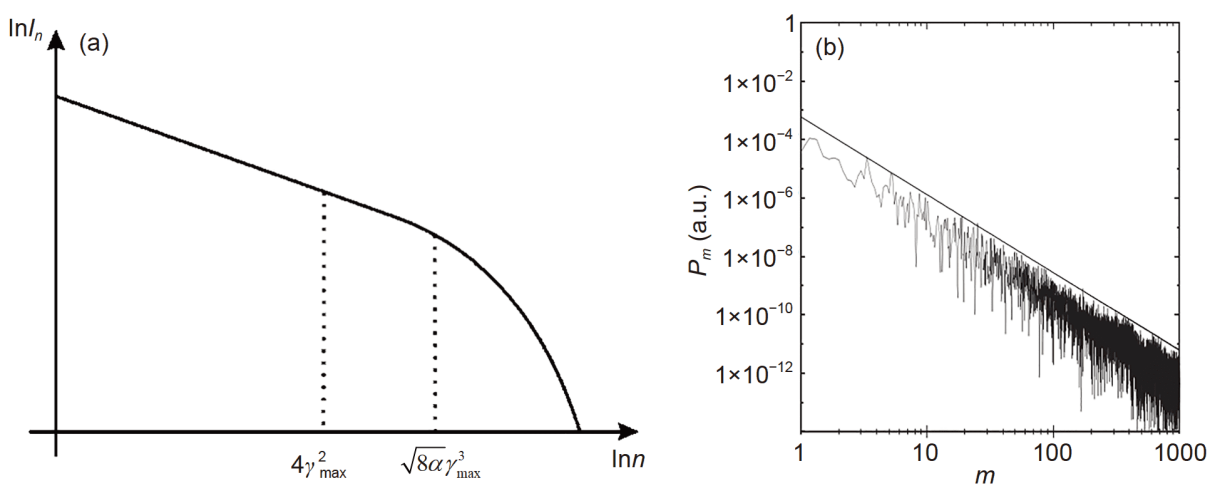

图 3 相对论振荡镜模型产生的高次谐波光谱分布示意图 ${ }^{[7]}(a)$ 和数值模拟结果 ${ }^{[14]}(b)$. 图(a)表明其指数分布结构以及光谱截止位置. 其中, 横轴 为谐波级次的对数 $\ln n$, 纵轴为谐波强度的对数 $\ln I_{n}$. 图(b)中, 直线表示谐波光谱强度的定标律: $I \sim \omega^{-8 / 3}$

Figure 3 (a) Schematic diagram of the spectral distribution of high-order harmonics generated by the relativistic oscillating mirror model ${ }^{[7]}$, showing its exponential distribution structure and spectral cut-off position, where the horizontal axis is the logarithm of the harmonic order $n$, and the vertical axis is the logarithm of the harmonic intensity $I_{n}$. (b) Result of numerical simulations ${ }^{[14]}$. The line shows the scaling law of harmonic spectral intensity: $I \sim \omega^{-8 / 3}$

收能量，然后在一个极短的时间内以极高的强度释放 出来, 这个参数区域称为相对论电子弹簧( relativistic electronic spring, RES)区域. 研究发现, 在特定的激光 参数条件下，相对论激光与等离子体场共同作用可以 产生(超)高密度的纳米尺寸电子束, 该电子束可产生类 似同步辐射的光谱, 称为相干同步辐射(coherent synchrotron emission, CSE $)^{[16]}$. 其辐射产生的脉冲宽度可 短至9 as, 更重要的是, 其辐射光谱的强度定标律达到 $p=4 / 3$ 甚至可能是 $6 / 5$, 这对 $\mathrm{keV}$ 乃至更高光子能量的谐 波产生是非常有利的. 而且, 其产生的谐波场强可远超 人射激光脉冲的场强, 对于研究需要极端场强的物理 过程如强场量子电动力学(quantum electrodynamics, QED)具有重要意义. 相比于ROM机制, CSE机制需要 更高的激光强度, 往往需要 $10^{20} \mathrm{~W} \mathrm{~cm}{ }^{-2}$ 以上的光强. 此 外, CSE机制不仅需要足够高的光强和好的激光对比 度, 还需要满足其他条件, 比如特定的人射角, 才能有 效压缩等离子体形成高密度的纳米尺寸电子薄层，使 其产生高亮度的辐射.

复杂的等离子体环境为高次谐波产生提供了多种 可能的机制，对不同激光参数和不同靶结构设计的探 索为不断推进高亮度阿秒脉冲产生的研究提供了新的 机遇. 在非相对论情况下, 一种有效的产生方案是 Quéré等人 ${ }^{[17]}$ 发现的相干尾波发射(coherent wake emission, CWE $)$ 机制, 它可以在较低的光强 $\left(10^{15} \sim 10^{17} \mathrm{~W} /\right.$ $\mathrm{cm}^{2}$ )下高效率地产生高次谐波和阿秒脉冲. CWE的物 理机制为固体表面等离子体在激光电场作用下产生高 能电子, 然后激光脉冲在其等离子体临界面附近被反 射, 高能电子则可以穿透进人固体靶内部. 这个高能电
子会在固体靶内部诱导出等离子体振荡(等离子体波), 在满足相位匹配条件的情况下，该等离子体振荡会辐 射出高次谐波. 模拟结果表明, 虽然无法产生很高级次 的谐波(其最高谐波级次正比于 $\left(n_{\max } / n_{\mathrm{c}}\right)^{1 / 2}, n_{\max }$ 是等离 子体靶的最大电子密度, $n_{\mathrm{c}}$ 是驱动激光波长对应的临界 电子密度), 但是该谐波的产生效率非常高, 理论上全谱 范围内可达到 $10^{-4}$ 的水平. 结合阿秒灯塔(attosecond lighthouse)技术 ${ }^{[18]}$, 该机制可能产生极高峰值功率的单 阿秒脉冲, 实验中已获得连续光谱, 是目前最有可能得 以实现单阿秒脉冲的技术.

\section{2 实验研究进展}

随着高功率飞秒激光技术的发展, 固体等离子体高 次谐波实验近些年进展迅速, 研究者在ROM和CWE机 制方面开展了大量研究, 也有少部分工作开始进人CSE 机制的参数区域. 飞秒激光脉冲与固体等离子体相互作 用实验早期的工作在不同靶材、不同激光参数上开展 了许多研究, 主要的结论之一是激光对比度对高次谐波 产生效率有极其重要的影响. 随着激光对比度的提高, 高亮度高次谐波产生研究得以迅速发展. Dromey等 人 $^{[19,20]}$ 首次在Vulcan的拍瓦激光系统上通过双等离子 体镜将激光对比度从 $10^{7}$ 提高到 $10^{11}$, 观测到水窗波段高 次谐波比没有等离子体镜的情况下产生效率提高了 100 倍左右, 高达 $10^{-6}$. 最高光子能量也迅速被推进到了 $3.8 \mathrm{keV}$ ，并在 $3 \mathrm{keV}$ 附近产生了高达 $5 \mu \mathrm{J}$ 左右的高亮度 谐波辐射. 这两个实验均基于ROM模型. 由于激光对比 度对高次谐波辐射效率具有决定性的影响, 国内也进行 了相关的实验研究. Gao等人 ${ }^{[21]}$ 的研究发现，谐波辐射 
效率对等离子体标度长度的依赖存在两个最优值, 且与 激光脉冲的人射角有关. 激光脉冲人射到固体靶面的角 度越大, 其中一个最优等离子体标度长度值也会越大.

CWE机制作为相对论光强以下的重要谐波辐射机 制, 虽然其最高谐波级次受等离子体靶最高电子密度 的限制而无法产生很高级次的高次谐波辐射，但是利 用大能量的泵浦激光可以产生极高亮度的高次谐波辐 射. 如果用气体高次谐波方案产生相同亮度的辐射, 则 可能会需要百米量级长度的装置. Quéré等人 ${ }^{[17]}$ 的实验 研究表明, CWE机制只出现在等离子体标度长度很短 的情况下. 进一步的实验和数值模拟表明 ${ }^{[22,23]}, \mathrm{CWE}$ 机 制虽然不需要很高的光强, 但是其最优的等离子体标 度长度却在 $0.01 \lambda$ 的量级水平, 这意味着对激光脉冲对 比度的要求是极高的.

工作在更高激光强度下的CSE机制是近几年的重 要研究对象. Dromey等人 ${ }^{[24]}$ 首次开展了CSE机制产生 高次谐波辐射的研究, 通过采用 $200 \mathrm{~nm}$ 厚的薄膜靶在 透射方向上测量高次谐波，从而避免在反射方向上与 $\mathrm{ROM}$ 机制产生的谐波辐射混淆, 测量了不同厚度的薄 膜靶产生的高次谐波强度随谐波级次的定标律. 实验 结果表明, 不同厚度的靶虽然定标律指数 $p$ 有不同的数 值, 但是均小于ROM机制的 $8 / 3$, 证实了CSE机制的存 在. 随后, 开展了一系列相关的实验 ${ }^{[25]}$ 和理论 ${ }^{[26]}$ 、阿秒 脉冲产生 ${ }^{[27]}$ 、纳米双层薄膜靶 ${ }^{[28]}$ 等研究. 其中, 关于 CSE机制下激光椭偏度影响的研究表明, 偏振门方案在 CSE机制下仍然有效, 可以利用少周期激光脉冲和偏振 门技术产生单阿秒脉冲 ${ }^{[25]}$. 纳米双层薄膜靶是一个有 意思的方案. $\mathrm{Xu}$ 等人 ${ }^{[29]}$ 最近发现，利用双层靶之间的 静电场及其不稳定的特性，有可能利用多周期的激光 脉冲驱动产生 $100 \mathrm{TW}$ 功率水平的单阿秒脉冲.

作为一种高亮度的宽带相干光源，其能否用于产 生阿秒脉冲, 光谱相位特性是一个重要的研究对象. Thaury等人 ${ }^{[30]}$ 通过干涉条纹法测量证明ROM机制产生 的高次谐波具有很好的相干性. Quéré等人 ${ }^{[31]}$ 则通过改 变激光脉冲的啁啾特性研究了高次谐波的光谱变化, 证明ROM机制和CWE机制具有不同的相位特性. 这些 结果都表明, 高强度相对论激光与等离子体相互作用 产生的高次谐波具有很好的相干性和相位分布，为高 强度阿秒脉冲的产生奠定了基础.

在阿秒脉冲产生方面, Wheeler等人 ${ }^{[18]}$ 在CWE机制 上结合灯塔技术, 清晰地观测到了高次谐波光谱随激 光载波包络相位的变化, 证明了单阿秒脉冲产生的可
行性. 周期振荡的激光脉冲一般每(半)个光周期产生一 个阿秒脉冲. 灯塔技术是一种将激光脉冲的时域变化 变换到角分布变化的技术, 从而将不同(半)周期产生的 阿秒脉冲分布于不同的角度，通过空间选择的方式获 得单阿秒脉冲. 该实验表明, 等离子体高次谐波可受亚 周期激光电场的控制，等离子体的集体运动也可实现 亚周期的激光电场控制，谐波辐射具有很好的相干性， 可通过激光电场控制产生单阿秒脉冲, 这对单阿秒脉 冲的产生研究非常重要. 一般来说, 大部分激光系统产 生的激光脉冲均为多周期的，这导致其只能产生多个 阿秒脉冲链，只有通过对激光脉冲波形整形或者等离 子体靶的设计, 才有可能产生单阿秒脉冲.

\section{3 总结与展望}

阿秒时间尺度是目前人类能掌控的最高时间分辨， 但是阿秒洜浦/阿秒探测的最终方案非常难以实现, 因 此高亮度的阿秒脉冲产生是阿秒科学领域一直追求的 目标. 随着高功率飞秒激光技术的发展, 相对论高次谐 波和阿秒脉冲的产生研究将是高亮度阿秒脉冲产生的 重要途径, 尤其在 $\mathrm{keV}$ 光子能量高次谐波和阿秒脉冲产 生方面具有独特的优势, 因其不受激光强度限制的特 性使其可用于产生极高亮度的阿秒脉冲. 随着激光脉 冲可聚焦峰值功率密度的进一步提高, CSE机制在超 相对论光强下产生高亮度阿秒脉冲的研究正在进行

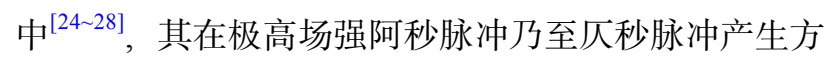
面可能具有独特的优势. ELI 阿秒(extreme light infrastructure-attosecond light pulse source, ELI-ALPS)装置 中, 固体等离子体高次谐波和阿秒脉冲产生是极其重 要的部分, 尤其是推进高亮度指标和高光子能量指标. 在脉冲能量方面，其第一期建立的目标是阿秒脉冲能 量达到微焦水平, 后续将推进到毫焦水平, 而光子能量 最高将达到数 $\mathrm{keV}^{[32]}$.

2005年, Science在其创刊125周年之际公布了 125 个最具挑战性的科学问题，其中第39个问题“What is the most powerful laser researchers can build?”根据量 子场论给出的理论值即施温格极限(光强 $2.3 \times 10^{29} \mathrm{~W} /$ $\mathrm{cm}^{2}$ ), 这显然是目前的钛宝石激光系统所无法达到的, 需要探索新的途径. 然而, Gonoskov等人 ${ }^{[33]}$ 的模拟表 明, 利用 $10 \mathrm{PW}$ 的激光系统有可能产生光强高达 $1.8 \times 10^{26} \mathrm{~W} / \mathrm{cm}^{2}$ (比洜浦激光光强高出近 3 个数量级)的 高次谐波脉冲，这意味着其将是研究上述科学问题的 一个可能途径. 


\section{参考文献}

1 McPherson A, Gibson G, Jara H, et al. Studies of multiphoton production of vacuum-ultraviolet radiation in the rare gases. J Opt Soc Am B, 1987, 4: 595-601

2 Hentslchel M, Kienberger R, Spielmann Ch, et al. Attosecond metrology. Nature, 2001, 414: 509-513

3 Paul P M. Observation of a train of attosecond pulses from high harmonic generation. Science, 2001, 292: 1689-1692

4 Gaumnitz T, Jain A, Pertot Y, et al. Streaking of 43-attosecond soft-X-ray pulses generated by a passively CEP-stable mid-infrared driver. Opt Express, 2017, 25: 27506

5 Krausz F, Ivanov M. Attosecond physics. Rev Mod Phys, 2009, 81: 163-234

6 Service R F. Laser labs race for the petawatt. Science, 2003, 301: 154-156

7 Baeva T, Gordienko S, Pukhov A. Theory of high-order harmonic generation in relativistic laser interaction with overdense plasma. Phys Rev E, 2006, 74: 046404

8 Kohlweyer S, Tsakiris G D, Wahlström C G, et al. Harmonic generation from solid-vacuum interface irradiated at high laser intensities. Opt Commun, 1995, 117: 431-438

9 von der Linde D, Engers T, Jenke G, et al. Generation of high-order harmonics from solid surfaces by intense femtosecond laser pulses. Phys Rev A, 1995, 52: R25-R27

10 Lichters R, Meyer-ter-Vehn J, Pukhov A. Short-pulse laser harmonics from oscillating plasma surfaces driven at relativistic intensity. Phys Plasmas, 1996, 3: 3425-3437

11 Bulanov S V, Naumova N M, Pegoraro F. Interaction of an ultrashort, relativistically strong laser pulse with an overdense plasma. Phys Plasmas, 1994, 1: 745-757

12 Gordienko S, Pukhov A, Shorokhov O, et al. Relativistic Doppler effect: Universal spectra and zeptosecond pulses. Phys Rev Lett, 2004, 93: 115002

13 Gordienko S, Pukhov A. Scalings for ultrarelativistic laser plasmas and quasimonoenergetic electrons. Phys Plasmas, 2005, 12: 043109

14 Boyd T J M, Ondarza-Rovira R. Anomalies in universal intensity scaling in ultrarelativistic laser-plasma interactions. Phys Rev Lett, 2008, 101: 125004

15 Edwards M R, Mikhailova J M. The X-ray emission effectiveness of plasma mirrors: Reexamining power-law scaling for relativistic high-order harmonic generation. Sci Rep, 2020, 10: 5154

16 an der Brügge D, Pukhov A. Enhanced relativistic harmonics by electron nanobunching. Phys Plasmas, 2010, 17: 033110

17 Quéré F, Thaury C, Monot P, et al. Coherent wake emission of high-order harmonics from overdense plasmas. Phys Rev Lett, 2006, 96: 125004

18 Wheeler J A, Borot A, Monchocé S, et al. Attosecond lighthouses from plasma mirrors. Nat Photonics, 2012, 6: 829-833

19 Dromey B, Zepf M, Gopal A, et al. High harmonic generation in the relativistic limit. Nat Phys, 2006, 2: 456-459

20 Dromey B, Kar S, Bellei C, et al. Bright multi-keV harmonic generation from relativistically oscillating plasma surfaces. Phys Rev Lett, 2007, 99: 085001

21 Gao J, Li B, Liu F, et al. Double optimal density gradients for harmonic generation from relativistically oscillating plasma surfaces. Phys Plasmas, 2019, 26: 103102

22 Kahaly S, Monchocé S, Vincenti H, et al. Direct observation of density-gradient effects in harmonic generation from plasma mirrors. Phys Rev Lett, 2013, 110: 175001

23 Gao J, Liu F, Ge X L, et al. Influence of laser contrast on high-order harmonic generation from solid-density plasma surfaces. Chin Opt Lett, 2017, 15: 081902

24 Dromey B, Rykovanov S, Yeung M, et al. Coherent synchrotron emission from electron nanobunches formed in relativistic laser-plasma interactions. Nat Phys, 2012, 8: 804-808

25 Yeung M, Dromey B, Cousens S, et al. Dependence of laser-driven coherent synchrotron emission efficiency on pulse ellipticity and implications for polarization gating. Phys Rev Lett, 2014, 112: 123902

26 Cherednychek M, Pukhov A. Analytical approach to high harmonics spectrum in the nanobunching regime. Phys Plasmas, 2016, 23: 103301

27 Cousens S, Reville B, Dromey B, et al. Temporal structure of attosecond pulses from laser-driven coherent synchrotron emission. Phys Rev Lett, 2016, 116: 083901

28 Xu X R, Qiao B, Chang H X, et al. Coherent synchrotron emission in transmission with double foil target. Plasma Phys Control Fusion, 2018, 60: 045005

$29 \mathrm{Xu} \mathrm{X}$, Zhang Y, Zhang H, et al. Production of 100-TW single attosecond X-ray pulse. Optica, 2020, 7: 355

30 Thaury C, George H, Quéré F, et al. Coherent dynamics of plasma mirrors. Nat Phys, 2008, 4: 631-634

31 Quéré F, Thaury C, Geindre J P, et al. Phase properties of laser high-order harmonics generated on plasma mirrors. Phys Rev Lett, 2008, 100: 095004

32 Tajima T, Barish B C, Barty C P, et al. Science of extreme light infrastructure. In: 1st International Conference on Light at Extreme Intensities (LEI 2009), Brasov, 2010, 1228: 11

33 Gonoskov A A, Korzhimanov A V, Kim A V, et al. Ultrarelativistic nanoplasmonics as a route towards extreme-intensity attosecond pulses. Phys Rev E, 2011, 84: 046403 


\title{
Theoretical and experimental progress of high-order harmonics and attosecond pulse generation based on solid overdense plasma
}

\author{
Jiaqi $\mathrm{Wu}^{1,2}$, Zhinan Zeng ${ }^{2 *} \&$ Ruxin $\mathrm{Li}^{1,2}$ \\ ${ }^{1}$ School of Physical Science and Technology, ShanghaiTech University, Shanghai 201210, China; \\ ${ }^{2}$ State Key Laboratory of High Field Laser Physics, Shanghai Institute of Optics and Fine Mechanics, Chinese Academy of Sciences, Shanghai 201800, \\ China \\ * Corresponding author, E-mail: zhinan_zeng@mail.siom.ac.cn
}

Since the laser was invented, harmonic generation and wavelength conversion have been important research topics in nonlinear optics regime. In 1987, McPherson A et al. used sub-picosecond $\mathrm{KrF}$ laser (248 nm wavelength) to interact with noble gas to obtain high-order harmonics for the first time. In 2001, the first single attosecond $\left(10^{-18} \mathrm{~s}\right)$ pulse with a pulse width of 650 as was measured experimentally by Krausz et al. by using the broadband high-order harmonic generation. Since then, high-order harmonics and attosecond pulses have been widely used in atomic and molecular physics, materials science and other fields. However, due to the low efficiency of attosecond pulses generated by the gas media, the energy of attosecond pulses is limited, which limits the detection methods of attosecond time dynamics research (currently mainly IR + XUV pumping/detection) and its applications in many fields. How to obtain high-brightness, high-energy attosecond pulses has always been the pursuit in this field since the generation of the first attosecond pulse. With the development of femtosecond laser technology, the output peak power of the femtosecond laser system has been rapidly increased in the past two decades. At present, the laser system can output the pulse with a peak power of up to $10 \mathrm{PW}\left(1 \mathrm{PW}=10^{15} \mathrm{~W}\right)$. Its intensity can be much higher than $10^{18} \mathrm{~W} / \mathrm{cm}^{2}$ and its interaction with the overdense plasma can efficiently generate highorder harmonics at the level of hundreds of $\mathrm{eV}$ or even $\mathrm{keV}$, which brings new opportunities for the development and application of high-order harmonics and attosecond pulses. Generally speaking, the interaction of high peak power femtosecond laser pulses with solid-density plasmas has unique advantages in high-luminance, high-energy high-order harmonics and attosecond pulse generation. In the ELI-ALPS plan, solid plasma high-order harmonics and attosecond pulse generation are very important parts, especially to promote their high brightness and their high photon energy. In terms of the attosecond pulse energy, the goal of their first phase is that the attosecond pulse energy reaches the $\mu \mathrm{J}$ level, which will be advanced to the $\mathrm{mJ}$ level in the next phase, and the photon energy of the attosecond pulse will reach a few $\mathrm{keV}$. This review gives a brief introduction to its physical mechanisms and their current experimental research progress. Three mechanisms (coherent wake emission (CWE), relativistic oscillating mirror (ROM), coherent synchrotron emission (CSE)) will be discussed. They are working under different laser intensity. CWE can emit high efficiency harmonics at the laser intensity below $10^{18} \mathrm{~W} / \mathrm{cm}^{2}$. But when the peak laser intensity is very high, the research of the CSE mechanism shows the generation of high-luminance high-order harmonics under super-relativistic light intensity, which can be used to produce extremely high field-strength pulse of attoseconds, even tens of zeptoseconds. If the laser parameters and the plasma condition can be well controlled, the laser pulse may even generate higher harmonic radiation with field strength much higher than the pump laser field strength, which may be a possible way to study the 39th question ("What is the most powerful laser researchers can build?") among the 125 most challenging scientific questions published by Science on its 125 th anniversary.

high-order harmonics, attosecond pulse, relativistic laser, plasma

doi: 10.1360/TB-2020-0585 